Бұл CC BY-NC-ND лицензиясы бойынша ашық жарыққа шыққан қол жетімді мақала (https://creativecommons.org/licenses/by-nc-nd/3.0/)

«Ғылымның өзекті мәселелері» - Халықаралық практикалық интернет- конференция материалдары

Басылым II, Қараша 2019

ISBN 978-601-323-144-0

https://doi.org/10.31643/2019.003

\author{
Айжан Юнусова \\ Абай атындағы ҚазҰПУ \\ E-mail: aizhan0296@mail.ru \\ ORCID ID 0000-0002-5076-4637
}

\title{
Болашақ менеджерлердің басқару мәдениетін қалыптастыру
}

\begin{abstract}
Абстракт: Автор мақалада болашақ менеджерлердің басқару мәдениетін қалыптастыру туралы қарастырады. Болашақ білім беру ұйымдары жетекшісінің басқару мәдениетін қалыптастырудың өзектілігі қазіргі әлеуметтік-экономикалық жағдай тұрғысынан оқу орнында орын алатын процестерді басқарудың балама педагогикалық жүйелерін енгізудің объективті қажеттілігімен анықталады. Басқару мәдениетін меңгерукүрделі және ұзақ процесс, ол тұлғадан тек қана маңызды күш-жігерді ғана емес, сонымен қатар адамда белгілі бір нышанды талап етеді. Автор зерттеу барысында басқару мәдениетінің негізгі құрауышы компонееттері мен менеджер тұлғасын қалыптастырудағы басқару мәдениетінің функцияларын анықтады.
\end{abstract}

Тірек сөздер: Менеджмент, менеджер, білім беру, мәдениет, басқару, басқару мәдениеті, қалыптастыру.

Кіріспе. Соңғы жылдарда реформа барлық деңгейлерге және ең алдымен білім беру үдерісін басқаруға басымдық берілетін ұлттық жоба ретінде қаралған білім беруді жаңғырту проблемалары aca өзекті болуда. Кәсіптік білім беруді модернизациялау, бұл кәсіби біліктілігін және кәсіптікпедагогикалық мәдениетті ұдайы жетілдіру арқылы тиімді басқаруға қабілетті, бәсекеге қабілетті және кәсіби мобильді жоғары білікті маман дайындауды қамтиды. Демек, болашақ білім беру ұйымдары жетекшісінің басқару мәдениетін қалыптастырудың өзектілігі қазіргі әлеуметтікэкономикалық жағдай тұрғысынан оқу орнында орын алатын процестерді басқарудың балама педагогикалық жүйелерін енгізудің объективті қажеттілігімен анықталады. «Қазақстан-2050» стратегиясында «білім беру саласындағы менеджменттің аз дамығандығы, оны дамыту қажеттілігінің» көрсетілуі [1], Қазақстан Республикасында білім беруді дамытудың 2016-2019 жылдарға арналған мемлекеттік бағдарламасында «...қазіргі қоғамның басты талаптарының бірі басқарушылық құзыреті дамыған жаңа тұрпатты адамды қалыптастыру» екендігіне аса мән берілуі қазіргі өмір талабынан шыққан өткір мәселе [2].

Әдебиеттерге шолу. Психологиялық-педагогикалық, әлеуметтану және басқа да әдебиеттерді талдау кәсіби-педагогикалық мәдениетті қалыптастыру, оның ішінде оның басқару компонентінің мәселелерін зерттеулер. В.Н.Ахименко, Е.В. Бондарева, С.Е. Джаджа, И.Ф.Исаев, Г.Матеев, Н.С. Речкин, В.А. Сластенин және т.б ғалымдардың жұмыстарынан орын алғанын көрсетеді, онда басқарудағы тұлғаның рөлі, оның маңызды сипаттамалары, сондай-ақ басқару қызметінің мазмұны мен тиімділігін анықтайтын факторлар талданады.

Басқару мәселесінің ежелгі грек философтарынан бастап, түркі ғұлама ойшылдарының еңбектерінде қарастырылғаны туралы, олардың құнды жазбаларындағы мемлекеттік басқарушының рөлі, ізгілікті басқару, басқарудың адамгершілік қағидалары жайлы ой-пікірлерін топтастыру, жіктеу мәселелері С. Қ. Қалиев, С. А. Ұзақбаева, А. Н. Көшербаева, Ұ. М. Әбдіғапбарова және т.б. ғалымдар еңбектерінде көрініс алған.

"Менеджердің басқару мәдениеті "ұғымын анықтау үшін оның компоненттерінің семантикалық өрісін қарастырамыз. "Менеджердің басқару мәдениеті" ұғымының негізінде жатқан 
құрамдас бөліктердің бірі "менеджер"термині болып табылады. Менеджер (ағыл. manager басқарушы), қазіргі заманғы өндіріс жағдайында басқару жөніндегі мамандар (кәсіпорындар, фирмалар, ұйымдар басшылары, әртүрлі басқарушылар) [3. 97, 189 б.]. «Менеджмент» сөзі оны ағылшын тілінде қолдануға негізделген тәжірибеге ие. "Менеджмент" ұғымының өзі көптеген келіспеушіліктер тудырады. Кеңес дәуірінде бұл сөз "басқару" сөзімен алмастырылды, олар менеджмент деп әлеуметтік-экономикалық мақсаттарға жету үшін басқару субъектісінің объектіге басқарушы әсерін түсінді. Әдебиеттер аудармасында менеджмент ұғымы персоналдарды басқарудағы ұйымдастырушылық-психологиялық әдіс деп түсіндіріледі. Шетел сөздігінде [4] "менеджмент" сөзі былайша аударылады: "өндірісті басқару, өндірістің тиімділігін және оның пайдасын арттыру мақсатында өндірісті басқару принциптері, әдістері, құралдары мен нысандарының жиынтығы".

"Менеджмент" ұғымымен салыстырғанда "басшылық", "ұжымды басқару", "өндірісті басқару" терминдері жеке болып табылады. "Менеджмент" терминін қолданудың қазіргі заманғы тәжірибесі оның негізгі үш мәнін қамтиды: ұйымдарда адамдарды басқару процесі; басқару ғылымы; басқару органы және оны құрайтын адамдар.

Э. А. Уткин [5, 8 б.] менеджмент "кәсіпорынның нарықтық жағдайда әрекет ететін, менеджменттің әлеуметтік-экономикалық тетігінің алуан түрлі принциптерін, функциялары мен әдістерін қолдану негізінде оңтайлы шаруашылық нәтижелеріне қол жеткізуге бағытталған кәсіби қызметтің ерекше түрі болып табылады деп есептейді" және оның жалпы анықтамасын береді: "менеджмент - бұл бағдарламалық-мақсатты басқару, ғылыми-техникалық әзірлемелерді ағымдағы және перспективалық жоспарлау және болжау, өндірісті ұйымдастыру, шаруашылық жүргізудің тиімділігін арттыру, нарық пен жалпы қоғамның қажеттіліктерін қанағаттандыру, пайданы ұлғайту мақсатында өнімдер мен қызметтерді сату жүйесі" [5, 9 б.].

Л. К. Аверченко және т.б. [6, 28 б.] психологиялық тұрғыдан алғанда менеджмент - адам сипаты мен мінез-құлқы туралы негіз қалаушы түсініктерді ескере отырып, адамдарды басқаруды жүзеге асыру процесі,-деп қорытындылайды.

Менеджмент адам тарихының барлық кезеңдерінде адам тәжірибесін ұйымдастыру мен үйлестірудің, оны әлеуметтендірудің маңызды формаларының бірі болып табылады. Әлеуметтік феномен және кез келген әлеуметтік процесс ретінде басқару мәдени мазмұнға ие [7, 8 б.]. Дәл осы мәдениет ұйым қызметінің барлық салаларына, соның ішінде басқаруға тікелей әсер етеді. "Әлемдік мәдениеттің жетістіктерін және оның ұлттық ерекшелігін пайдалану, ақиқатқа, жақсылық пен сұлулыққа, руханилыққа және жалпы адамзаттық құндылықтарға бағдар беру ұйымдардың өздерінің сипаттарына, оларды басқару факторларына айналады" [7, 11 б.].

Педагогикалық, психологиялық, әлеуметтану әдебиеттерін талдау басқарушының қызметі мен жеке басы ғылымның әр түрлі салаларын зерттеу объектісі болып табылатынын көрсетеді. Менеджмент жалпы адам капиталының және атап айтқанда қоғамның маңызды элементі болып табылатыны белгілі. Менеджмент тарихы өз тамырымен терең өткенге кетеді, өйткені менеджер қызметінің тәжірибесі адамзаттың мыңжылдықтармен жинақталды.

Менеджменттегі мәдени факторы рөлінің өсуі қазіргі жағдайдың маңызды талаптарының бірі. Психологиялық-педагогикалық мағынада мәдениет "адамдардың өмірі мен қызметін ұйымдастыру түрінде, олардың өзара қарым-қатынасында, сондай-ақ олардың жасаған материалдық және рухани құндылықтарында адамның шығармашылық күші мен қабілеттерінің тарихи белгілі бір даму деңгейі" ретінде қарастырылады [8, 221 б.].

Отандық мәдениеттанудағы екі зерттеу бағыты басым. 60-шы жылдардың ортасынан бастап мәдениет адам жасаған материалдық және рухани құндылықтардың жиынтығы ретінде қарастырылды. Мәдениет интерпретациясының аксиологиялық концепциясы құндылықтар әлемі деп атауға болатын адам болмысының саласын есептеу болып табылады. Іс-әрекеттік тұжырымдаманың жақтаушылары (Э. Маркарян) мәдениет ұғымын мұндай түсіндіруде белгілі шектеулікті қарастырады. Олардың пікірінше, аксиологиялық интерпретация тар саладағы мәдени құбылыстарды байқатады, ал "мәдениет диалектикалық жүзеге асырылатын процесс оның объективті және субъективті сәттері, алғышарттары мен нәтижелері бірлігінде". Соңғы онжылдықтағы отандық мәдени әдебиеттегі бұл авторлар мәдениеттің мәнін технологиялық тұрғыдан ойлаудың белсенді қорғаушылары ретінде белгілі. Педагогикалық мәдениет басқару мәдениетінің негізі болып табылады, қазіргі уақытта оны зерттеуге көп көңіл бөлінеді. В. А. Сластенин: "басқару мәдениеті 
мектепті басқаруда құндылықтар мен технологияларды игеруге, беруге және құруға бағытталған басқару қызметінің әртүрлі түрлерінде басшының тұлғасын шығармашылық тұрғыдан өзін-өзі іске асырудың өлшемі мен тәсілін білдіреді" [9, 439 - 440 б.]. Н. М. Таланчук басқару мәдениетін "тәрбие үрдісін басқарудың нақты міндеттерін шешу кезінде объективті басқару функцияларын жүзеге асыру бойынша жетекшінің қызметін жетілдіру шарасы" ретінде қарастырады [10, 69 - 76 б.].

Зерттеудің нәтижесі. "Басқару мәдениеті" түсінігі "мәдени басқару "ұғымына жақын. Алайда олар бірдей емес. Біріншісі маманның кәсіби-тұлғалық қасиеттерін, екіншісі - оның қызметін сипаттайды. Басқару мәдениеті басқару мәдениетінің маңызды шарты болып табылады, бірақ мұндай бөлу бөлу салыстырмалы болып табылады. Басқару мәдениеті қоғамдағы қарым-қатынастың өркениеттік деңгейін куәландыратын өзіндік индикатор ретінде қарастырылады. Оның жай-күйі қоғамның өзінің диагнозы үшін маңызды, себебі адамзаттың прогресі адам өмірінің детерминациясындағы мәдениеттің рөлін күшейтуде көрінеді. Әдебиетте басқару мәдениеті ұғымының көптеген анықтамалары бар, бұл оның күрделілігі мен көпаспектілігін көрсетеді.

Басқару мәдениеті - бұл басқару білімдерінде көрсетілген "инвериоризацияланған әлеуметтік басқару тәжірибесі"; басқару қызметінің түрлі түрлерін, оның ішінде шығармашылық қызметті жүзеге асыру тәжірибесі; сондай-ақ басқарушылық өзара іс-қимыл процесіндегі құндылық қарымқатынас тәжірибесі, қарым-қатынас нормалары туралы білімді және осы нормаларды сақтаудағы дағдыны болжайтын тәжірибе.

В. В. Кузнецов басшының басқару мәдениетін тұтас динамикалық жүйе ретінде қарастыра отырып, оны жеке басын, қарым-қатынасын және кәсіби қызметін сипаттайтын компоненттер түрінде көрсетеді [11, 36 б.]. Басқару мәдениетінің негізгі құрауыштары ретінде мыналарды бөлеміз (Төмендегі кестені қараңыз):

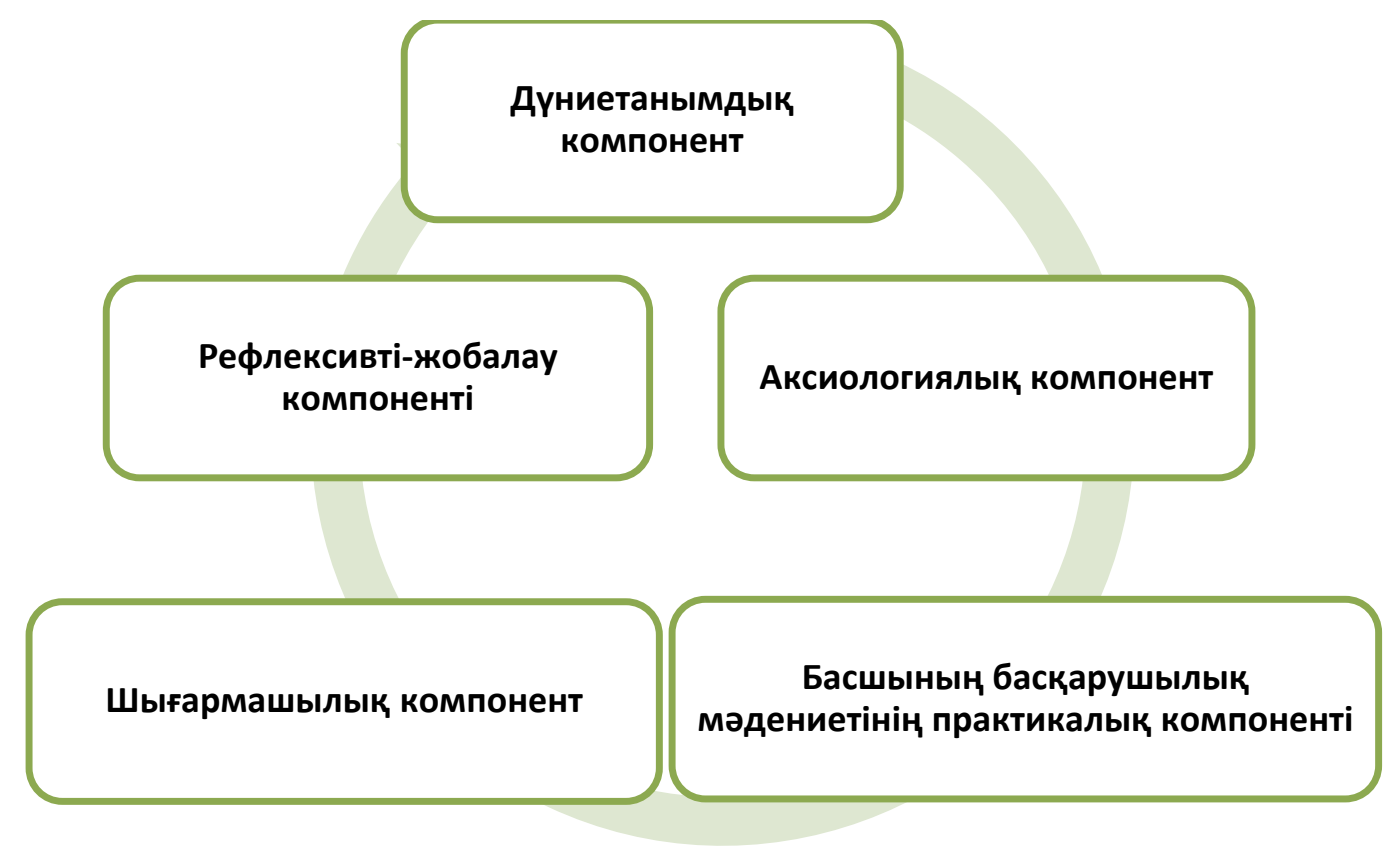

Басқару мәдениетінің негізгі құрауышы компонееттері

> Дүниетанымдық компонент: сенімдер, мүдделер, артықшылық, басшының бағдары.

$>$ Аксиологиялық компонент: бұл басшының басқару еңбегінің құндылықтарынан тұрады.

$>$ Басшының басқарушылық мәдениетінің практикалық компоненті олардың қарамағындағылармен өзара іс-қимылының сипатын, жоспарлау, ұйымдастыру, уәждеу, бақылау әдістерін, басқару тәсілдері мен технологияларын, ақпараттық технологияларды, құжаттауды меңгеру деңгейін ашады. 
Шығармашылық компонент іс жүзінде тығыз байланысты және басшының жоспарлау, ұйымдастыру, мотивация және бақылау мәселелеріне стандартты емес қарау қабілеттілігінен көрінеді.

> Рефлексивті-жобалау компоненті басшының рефлексивті-ойлау мәдениетінде, оның маңызды күштерінің өзін-өзі іске асыруында көрінеді.

Менеджердің басқару мәдениеті менеджер тұлғасының біртұтас мәдениетінде біріктіруші бастама болып табылады; ол білім, білік, басқару дағдыларын, әсіресе ғылыми білімді практикалық қызметте, қызметтің барлық салаларына біріктіруге ықпал етеді. Демек, басқару мәдениетінің мәні біз кешенді тұлғалық білім ретінде түсінеміз:

$>$ білім мен іскерлікті меңгерудің жоғары деңгейі сапалы және өнімді басқару дайындығы үшін;

$>$ оның процесіне, құралдарына және нәтижелері;

$>$ қоғамның әлеуметтік-экономикалық дамуының нақты кезеңінің талаптарына сәйкес келетін және адамға танымдық және пәндік-қайта құрушы қызметте өзін толық іске асыруға мүмкіндік беретін еңбек қатынастарының тәжірибесі.

Менеджер тұлғасын қалыптастырудағы басқару мәдениетінің функциялары:

4 тұлғаны заманауи қоғамдық қатынастар жүйесіне қосу;

* жалпы және нақты басқаруды жүзеге асыруға менеджерді дайындау;

* бағынысты әріптестердің кәсіби бағдар берудің ғылыми негізделген жүйесін ұйымдастыру үшін алғышарттар жасау;

4 менеджер функцияларын орындау жолдарын еркін таңдау үшін жағдайларды қамтамасыз ету;

\$ менеджердің қызметін өзін-өзі ұйымдастыру және өзін-өзі жүзеге асыру арқылы басқару сапасына кепілдік беру.

Оку-тәрбие қызметінің феномені ретінде басқару мәдениетінің тұтастығы мен жүйелілігі онда 3 құрылымдық компоненттердің болуын болжайды:

$\checkmark$ интеллектуалдық (басқару қызметінің білімі мен білігі);

$\checkmark$ эмоционалдық-құндылық (қарым-қатынас және орнату);

$\checkmark$ практикалық іс-әрекет (ойлау мәдениетін, қарым-қатынас, іс-әрекет тәсілдерін және т. б. көрсету тәжірибесі).

"Мәдениет" нормаларын басшылыққа ала отырып, әртүрлі дәрежедегі басқарушылар қатаң әкімшілік ету процесін жеңілдетеді, бұл ұйымды басқарудың нәтижелілігін арттыруға ықпал етеді.

қорытынды. Басқарушылық құзыреті дамыған жаңа тұрпатты адамды қалыптастыру қазіргі өмір талабынан шыққан өткір мәселе. Болашақ менеджерлердің басқару мәдениетін қалыптастыру да сол секілді бүгінгі күннің өзекті мәселелерінің бірі. Басқару мәдениетін меңгеру- күрделі және ұзақ процесс, ол тұлғадан тек қана маңызды күш-жігерді ғана емес, сонымен қатар үнемі ізденісте болуды талап етеді. Басқару мәдениеті- күрделі, көп қырлы, кешенді сипатқа ие құбылыс. Сондықтан да, білімді, эффективті басқарушы менеджер тұлғасын қалыптастыруда мына қасиеттер үлкен маңызға ие. Олар: тұлғалық, кәсібилік, мәдениеттанушылық. 


\author{
Aizhan Yunussova \\ Abai KazNPU, Kazakhstan \\ E-mail: aizhan0296@mail.ru \\ ORCID ID 0000-0002-5076-4637
}

\title{
Formation of management culture of future managers
}

\begin{abstract}
The author considers the formation of management culture of future managers in the article. The relevance of the management culture of the leader of the future educational organizations is determined by the objective need for the introduction of alternative pedagogical systems of management of processes that occur in the educational context in terms of the current socio-economic situation. Acquiring a culture of management is a complex and long process, requiring not only the most important efforts of a person, but also a specific character. During the research, the author defined the functions of the culture of managing and the formation of the main components of management culture and the managers' personality.
\end{abstract}

Keywords: Management, manager, education, culture, management, culture of management, formation.

Бұр мақалаға сілтеме: Юнусова, А., (2019) Болашақ менеджерлердің басқару мәдениетін қалыптастыру. «Ғылымның өзекті мәселелері» - Халықаралық практикалық интернет- конференция материалдары / Materials of International Practical Internet Conference "Challenges of Science". ISBN 978-601-323-144-0. Басылым II, 2019. Бет: 20 - 24. https://doi.org/10.31643/2019.003

\section{Пайдаланылған әдебиеттер тізімі}

[1] Қазақстан Республикасының Президенті Н.Ә.Назарбаевтың Қазақстан халқына жолдауы «Қазақстан жолы - 2050: Бір мақсат, бір мүдде, бір болашақ». - Астана, 2014. - 17 қаңтар.

[2] Қазақстан Республикасында білім беруді және ғылымды дамытудың 2016-2019 жылдарға арналғанмемлекеттік бағдарламасы. - Астана, 2016, - 1 наурыз

[3] Meisel S., Seltrer J. Rethinking Management Education: A TQM Perspective //Journal of Management Education. - 1995. February. -Vol. 19, №1. - P. 75-95.

[4] Ожегов, С. И. Словарь русского языка: 70000 слов Текст. / С. И. Ожегов ; под ред. Н. Ю. Шиловой. М.: Рус. яз., 1989. - $924 \mathrm{c}$.

[5] Уткин Э. А. Основы мотивационного менеджмента Издательство: ЭКМОС, 2000 г.

[6] Аверченко, Л. К. Психология управления Текст. / Л. К. Аверченко. М.: ИНФРА-М, 2002. 150 с.

[7] Адамский А.И. Управление развитием // Первое сентября.- № 16 (17 февраля).- 1997.

[8] Бодалев А.А. Личность и общение: избр. тр.- М.: Педагогика, 1998.-272c. 24

[9] Сластенин В.А. Идея комплексного подхода к воспитанию и подготовке учителя. Приобщение к педагогической профессии: практика, концепция, новые структуры. - Воронеж, 1992.

[10] Афанасьева Т.П. Программа и технология активного обучения директоров школ методам руководства коллективом: дис. ...канд. пед. наук. - М. 1998

[11] Кузнецов В.В. Управленческая культура ру- ководителя: (управление в постиндустриальном об- ществе): учебное пособие / В.В. Кузнецов, О.В. Ор- ловская. М.: Эгвес, 2013. 